\title{
Isolamento e propagação da Ehrlichia canis em células DH82 e obtenção de antígeno para a reação de imunofluorescência indireta
}

\section{Isolation and propagation of Ehrlichia canis in DH82 cells as a source of antigens in indirect immunofluorescence test}

\author{
Helenita Marques Torres, ${ }^{\star}$ Carlos Luiz Massard, ${ }^{\star *}$ Marcio José de Figueiredo,* \\ Teresinha Ferreira, ${ }^{\star}$ Nádia Regina Pereira Almosny*
}

\begin{abstract}
Resumo
Ehrlichia canis, agente etiológico da Ehrlichiose Monocítica Canina, foi obtida a partir de um cão naturalmente infectado e propagada em outro por infecção experimental. A camada de mononucleares deste animal foi separada e inoculada em células macrofágicas de linhagem contínua de origem canina, denominadas DH82. A cultura apresentou-se positiva 18 dias pós a infecção. A propagação da Ehrlichia canis in vitro foi acompanhada a partir da observação de mórulas nas células presentes no sobrenadante da cultura infectada, pelas técnicas de citocentrifugação, inoculação em tubos de Leighton e imunofluorescência direta. O cultivo apresentou cerca de $30 \%$ de infecção após o $30^{\circ}$ dia, alcançando $80 \%$ no $47 \%$, sendo então dividido a 1:2. As células DH82 permitiram o isolamento de E.canis e foram utilizadas como fonte de antígeno para o teste de imunofluorescência indireta.
\end{abstract}

Palavras-chave: Ehrlichia canis, cultivo celular, células DH82, reação sorológica.

\begin{abstract}
Ehrlichia canis, the etiologic agent of Canine Monocytic Ehrlichiose, was isolated from a carrier dog and transmited experimentally to a healthy dog. The mononuclear cell population from the inoculated dog was separated and overlaid in a continuous macrophage cell line ( $\mathrm{DH} 82)$. The culture became positive 18 days after the addition of infective supernatant. The propagation of $E$. canis was checked for infectivity by cytocentrifugation, by growth in Leighton tubes and Direct Immunofluorescence Test. By day $30,30 \%$ of DH82 cells were infected and by day $47,80 \%$ of cells contained morulae. At this point, the culture was split $1: 2$. The DH82 cells allowed the isolation of E. canis, and were used as antigenic sources in Indirect Fluorescent Antibody Tests.
\end{abstract}

Keywords : Ehrlichia canis, culture cells, DH82 cells, serological test.

\section{Introdução}

O agente etiológico da Ehrlichiose Monocítica Canina (CME), a rickettsia Ehrlichia canis (E.canis), é uma diminuta bactéria cocóide, pleomórfica, gram-negativa, que parasita intracitoplasmaticamente monócitos circulantes e macrófagos do sistema reticuloendotelial, em grupos de organismos denominados mórulas (Troy e Forrester,1990). Atualmente são reconhecidas, de acordo com a seqüência do RNA ribossomal 16S, três cepas de E. canis: Flórida, Oklahoma e Israeli ( Harrus et al., 1997 a ). A E. canis é transmitida naturalmente pelo carrapato marrom do cão, o Rhipicephalus sanguineus e reconhecida como uma importante e potencial doença fatal de cães e outros membros da família Canidae (Ristic e Holland,1993). A patogênese da CME envolve três fases consecutivas: aguda, subclínica (com infecção persistente assintomática) e crônica. Os si- nais clínicos e patológicos podem variar, sendo mais freqüentes a depressão, letargia, anorexia, febre, linfadenomegalia, esplenomegalia, trombocitopenia associado a hemorragias e hipergamaglobulinemia (Harrus et al.,1997 b).

O diagnóstico laboratorial é confirmado pelo isolamento do agente (lqbal et al.,1994), pela visualização de mórulas em monócitos circulantes (Simpson,1972), pela demonstração do DNA na técnica da Reação em Cadeia da Polimerase (PCR) (Iqbal \& Rikihisa, 1994 a) e pela detecção no aumento do título de anticorpos no soro (Ristic et al., 1972). Dentre os testes sorológicos, a Imunofluorescência Indireta (IFI) é o mais recomendado (Harrus et al.,1998); entretanto, esta técnica só se tornou possível a partir dos experimentos de Nyindo et al. (1971), que se tornaram pioneiros em cultivar $E$. canis in vitro, em cultivo primário de monócitos sangüíneos periféricos, a partir de cães agudamente infectados, fornecendo ba-

\footnotetext{
* Profs. Adjuntos de Doenças Infecciosas, Departamento de Patologia e Clínica Veterinária da Universidade Federal Fluminense- Rua Vital Brazil Filho, 64, Vital Brazil- Niterói, RJ - CEP 24230-340.

**Prof. Titular, Departamento de Parasitologia Animal, IV, UFRRJ.
} 
ses para Ristic et al. (1972), desenvolverem a IFI. Hellmet et al. (1980) aprimoraram o cultivo, propagando a E. canis seriadamente a partir de culturas primárias de monócitos sanguíneos. Estas técnicas, embora bem-sucedidas para seus objetivos, requeriam manutenção do organismo por transferência seqüenciada de monócitos infectados, assim como um suprimento contínuo de células, sendo limitada, também, pelo tempo de vida dos monócitos caninos em cultivo primário. $O$ aprimoramento das técnicas sorológicas e um maior conhecimento sobre a estrutura e composição da $E$. canis tomaram novo vulto a partir das pesquisas de Dawson et al. (1991b) e Rikihisa et al. (1992) que utilizaram uma célula de origem canina, de linhagem contínua, isolada e estabilizada em 1988 por Wellman et al., a partir de um cão apresentando um quadro de histiocitose maligna. Esta célula, denominada $\mathrm{DH} 82$, se mostrou suscetível ao isolamento e propagação da $E$. canis e, embora ao longo da década passada outras linhagens celulares fossem experimentadas, a DH82 se tornou definitiva na maior parte dos grandes centros de pesquisa.

O primeiro relato da presença da $E$. canis no Brasil foi feito em 1973 em Belo Horizonte, Minas Gerais, por Costa et al., e embora outras notificações tenham sido feitas (Almosny,1998), a doença tem sido predominantemente diagnosticada através de achados clínicos e hematológicos, associados à demonstração de mórulas em leucócitos a partir de sangue periférico (Seibert et al., 1997; Munhoz e Babo, 1998). Entretanto, para Harrus et al. (1997 a), as mórulas de E.canis só são ocasionalmente demonstradas durante o estágio agudo da doença, devendo ainda ser criteriosamente pesquisadas. Segundo Harrus et al. (1998), esta técnica não funciona para cães na fase subclínica, o que exige provas mais sensíveis de diagnóstico.

No Brasil não se tem conhecimento do isolamento e propagação dessa bactéria, assim como não se dispõe de testes sorológicos de origem nacional. Estes testes são importados, caros e nem sempre disponíveis. Em função disso, o objetivo de nosso trabalho foi o isolamento da $E$. canis e a propagação deste agente em células $\mathrm{DH} 82$, visando a obtenção de antígenos para confecção de testes sorológicos.

\section{Material e métodos}

\section{Cão doador}

Sangue total heparinizado $(2,5 \mathrm{ml})$ foi obtido de um cão com sinais clínicos e hematológicos de ehrlichiose e histórico de infestação por carrapatos. $O$ animal apresentava-se magro, apático, anoréxico e com aumento de temperatura. Os sinais hematológicos limitavam-se a uma profunda trombocitopenia e monocitose. Mórulas foram identificadas nos monócitos em esfregaços de sangue periférico corados pelo método do Panótico Rápido-LB (Laborclin). A presença de anticorpos para $E$. canis no soro sangüíneo foi detectada através do teste de imunoabsorção enzimática (ELISA) (IDEXX Lab. Inc., USA).

\section{Cão receptor}

O sangue do cão doador foi inoculado intravenosamente em um cão receptor saudável, sem raça definida, com cerca de seis meses de idade, vermifugado, vacinado contra as princi- pais doenças caninas e com sorologia negativa para $E$. canis. Nenhuma alteração clínica ou hematológica foi observada antes da inoculação. Temperatura retal, apetite, comportamento ou qualquer alteração eram monitoradas diariamente. Uma amostra de sangue era coletada a cada cinco dias para confecção de hemograma completo e nos dias 10, 20, 40 e 80 uma amostra de soro foi guardada para sorologia. A cada dois dias era realizado um esfregaço de ponta de orelha para pesquisa de mórulas de $E$. canis. $O$ resultado positivo determinou a separação de monócitos circulantes usados para infectar cultivos de células $\mathrm{DH} 82$.

\section{Separação da camada de mononucleares}

A técnica de separação de leucócitos foi feita segundo lqbal et al. (1994). No décimo quinto dia pós a inoculação, 10ml de sangue heparinizado foram coletados do cão receptor, passados para tubos plásticos de centrífuga de $15 \mathrm{ml}$ (Corning) e centrifugados a $2.500 \times \mathrm{g} / 5$ minutos. O plasma foi guardado para sorologia $\mathrm{a}-20^{\circ} \mathrm{C}$ e a camada da interface do plasma e eritrócitos foi aspirada com pipeta Pasteur e cuidadosamente deixada escorrer pelas paredes do tubo de centrífuga contendo $7 \mathrm{ml}$ de Ficoll (Histopaque 1077-Sigma), sendo então centrifugado a $2000 \times \mathrm{g} / 15$ minutos. A interface contendo a fração mononuclear era aspirada e lavada duas vezes ( 500 x g / 5 minutos) em meio de cultura Dulbecco's Minimal Essencial Medium (DMEM- DIFCO). O sedimento, contendo a fração mononuclear, era ressuspenso em $3 \mathrm{ml}$ de meio de cultura (DMEM) contendo uma mistura de antibióticoantimicótico, usada numa diluição a 1:100 (10.000 U de penicilina $\mathrm{G} / \mathrm{ml}, 10.000 \mathrm{mg}$ de sulfato de estreptomicina / $\mathrm{ml}$ e 25 $\mathrm{mg}$ de anfotericina $\mathrm{B} / \mathrm{ml}$ ) adicionado de bicarbonato de sódio $(2,2 \mathrm{~g} / \mathrm{L})$ e suplementado com $1 \mathrm{mM}$ de piruvato de sódio e $10 \%$ de soro fetal bovino (DIFCO). Processava-se $200 \mathrm{ml}$ desta suspensão em citocentrífuga (Cytospin II - Wellman), corando-se a lâmina pelo Panótico-LB e observava-se em microscopia de imersão o nível de infecção dos monócitos.

\section{Inoculação da camada de mononucleares em células de linhagem contínua, DH82.}

As células DH82 foram obtidas do American Type Culture Collection (ATCC - CRL-10389), importadas através do Banco de Células da Universidade Federal do Rio de Janeiro (BC-RJ) e crescidas ern garrafas plásticas descartáveis de $25 \mathrm{~cm}^{2}$ (Corning), sendo mantidas de acordo com o método descrito por Dawson et al. (1991b). A suspensão de monócitos caninos primários, infectados com $E$. canis e ressuspenso em $3 \mathrm{ml}$ de DMEM completo foi adicionada ao cultivo da DH82 e a cada 30 minutos, nas primeiras duas horas, agitava-se a garrafa suavemente para permitir melhor contato entre os monócitos infectados e as células $\mathrm{DH} 82$, findas as quais adicionavam-se mais $2 \mathrm{ml}$ de meio (Rikihisa, comunicação pessoal). Esta garrafa era incubada em estufa a $37^{\circ} \mathrm{C}$ sem suplementação de CO2 e o meio era trocado a cada 48-72 h.

\section{Avaliação da infectividade}

A partir do $10^{\circ}$ dia pós inoculação, as culturas eram examinadas três vezes por semana para a presença de mórulas. Primeiramente $200 \mu \mathrm{l}$ do sobrenadante da cultura era centrifugado em citocentrífuga a $1000 \mathrm{rpm} / 5$ minutos e a lâmina, corada pelo Panótico-LB, era observada em microscopia de imersão 
(Gaunt et al., 1996). Paralelamente, $5 \mathrm{ml}$ eram centrifugados em centrífuga comum a $250 \times \mathrm{g} / 5$ minutos, o sedimento ressuspenso em $2 \mathrm{ml}$ de DMEM completo e semeado em tubos de Leighton, cuja lamínula era corada no dia seguinte e observada em imersão (Nyindo et al., 1971). Por ambas as técnicas se avaliava o percentual de células infectadas. A cultura foi monitorada, ainda, pelo método da Imunofluorescência Direta (IFD), utilizando-se um conjugado anti ehrlichia marcado com isotiocianato de fluoresceína (Merk), preparado a partir do soro de um cão naturalmente infectado e na fase clínica da doença (Carter et al., 1971; Massard, 1984), sendo o conjugado utilizado numa diluição a 1:10.

\section{Preparo das lâminas para a reação de imunofluorescência indireta e manutenção das culturas}

Quando as células apresentavam cerca de $80 \%$ de infecção, o sobrenadante da cultura era centrifugado e o sedimento ressuspenso em igual volume de meio. Uma gota da suspensão antigênica era depositada em lâminas (10 $\mu \mathrm{l})$ que eram secas à temperatura ambiente, fixadas em acetona por 30 minutos e estocadas a $-20^{\circ}$ até sua utilização (Rikihisa et al., 1992). A reação de IFI era processada segundo a técnica descrita por lqbal et al. (1994).

Tanto culturas de células DH82 não infectadas como cultivos apresentando $80 \%$ de infecção eram divididos a 1:2 para perpetuação da cultura; algumas amostras eram congeladas com dimetil sulfóxido (DMSO) em nitrogênio líquido, para manutenção de estoque, de acordo com a técnica preconizada por Doyle (1990).

\section{Resultados}

A inoculação de sangue de um cão doador com $E$. canis em um cão saudável reproduziu a doença, resultando no aparecimento de sinais clínicos e hematológicos no cão inoculado. No $12^{\circ}$ dia pós-infecção (PI) o animal apresentou os primeiros sinais clínicos de pirexia $\left(41^{\circ} \mathrm{C}\right)$ e anorexia, seguidos de corrimento ocular brando e posteriormente melena. Apresentava ainda trombocitopenia (80.000 plaquetas $/ \mathrm{mm}^{3}$ ) e ligeira anemia $(V G=32 \%)$. A visualização de mórulas em esfregaços de sangue periférico foi vista no $15^{\circ}$ dia $\mathrm{PI}$, não sendo mais detectada em torno do $32^{\circ}$ dia. $O$ título de anticorpos para $E$. canis no soro sangüíneo mostrou-se positivo pela prova de ELISA, no $20^{\circ}$ dia PI.

A camada de mononucleares obtida pela técnica do Ficoll, para inoculação na cultura, apresentou tanto monócitos contendo mórulas como monócitos apresentando corpúsculos de inclusão.

A cultura de células $\mathrm{DH} 82$ inoculada mostrou-se positiva para a presença de mórulas no citoplasma, 18 dias após a inoculação da camada de mononucleares e, inicialmente, apresentava poucas células infectadas e que continham, em média, de 1 a 3 mórulas por célula. Cerca de cinco dias após já se encontravam algumas células com alto nível de infecção, apresentando, em média, de 10 a 20 mórulas. Três dias depois, detectavam-se células cujo citoplasma se encontrava completamente obliterado pelas mórulas. Estas, apresentavam-se de tamanho variável, desde diminutas a grandes colônias (Figura 1).

A morfologia, tamanho e distribuição das mórulas no citoplasma das células DH82 infectadas e observadas por

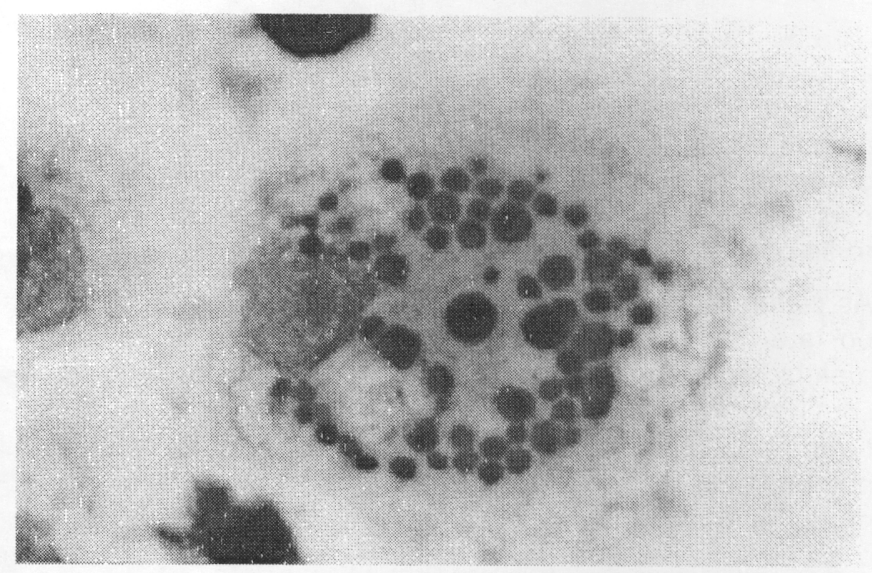

Figura 1: Mórulas de E. canis no citoplasma de células DH82. Coloração Panótico-LB - $1000 \mathrm{X}$

microscopia de imunofluorescência direta foram similares às observadas na coloração pelo Panótico-LB (Figura 2). Controles de cultivos de células $\mathrm{DH} 82$ não infectadas permaneciam livres de organismos e não apresentaram fluorescência específica (Figura 3).

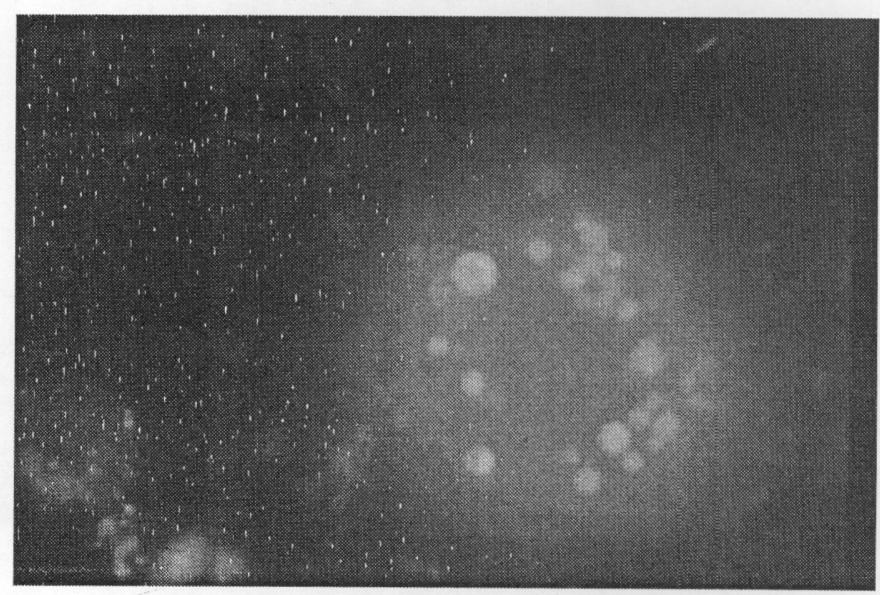

Figura 2: Mórulas de E. canis no citoplasma de células DH82. Coloração por imunofluorescência Direta - $1000 \mathrm{X}$

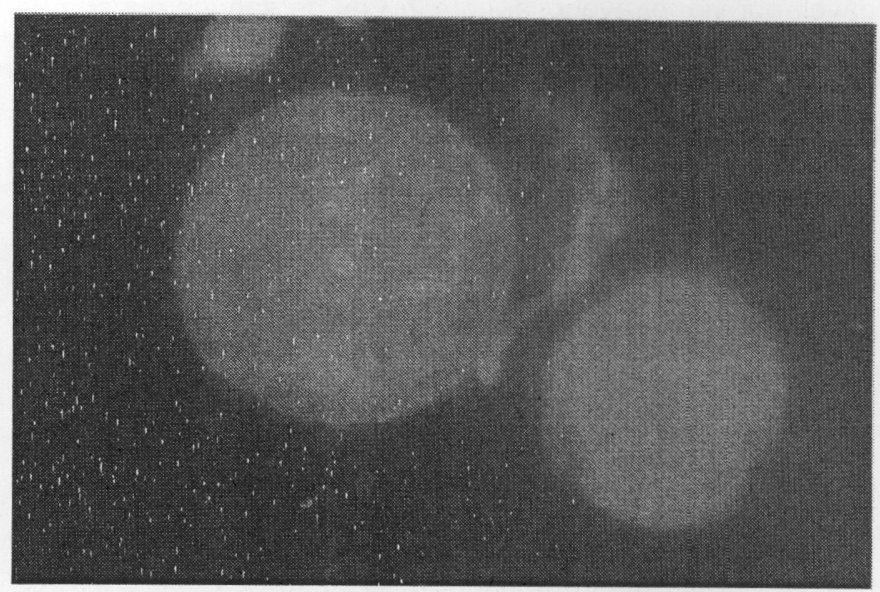

Figura 3: Células DH82. Controle não infectado. Coloração por Imunofluorescência Direta - $1000 \mathrm{X}$ 
No 28 dia pós infecção, o percentual de células infectadas alcançou cerca de $30 \%$ e continuou aumentando, atingindo $60 \%$ no $42 \%$ dia e, no $47 \%$ o $80 \%$ das células apresentavam mórulas. Cultivos com este percentual de infecção quando divididos a 1:2, retornavam a este patamar, cerca de cinco dias após, e assim sucessivamente, perpetuando novas culturas com alto nível de infecção.

As culturas de células $\mathrm{DH} 82$ não infectadas foram mantidas por até dois meses e meio, sem divisão, não ocasionando prejuízo aparente ao tapete celular, que se mostrava íntegro e com cada vez mais células livres no sobrenadante. Após este tempo começava a ocorrer uma apreciável diminuição do número de células da monocamada do tapete celular com predomínio de células de aspecto gigantes, multinucleadas e citoplasma bastante vacuolizado.

A Figura 4, demonstra a evolução dos níveis de anticorpos para $E$. canis no cão experimentalmente infectado, segundo a técnica de IFI, utilizando-se como antígenos as células DH82 altamente infectadas.

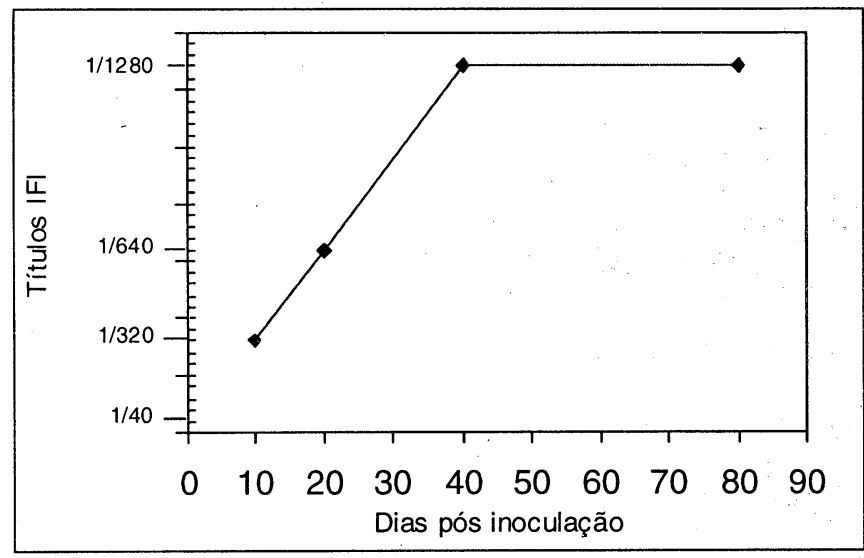

Figura 4: Evolução dos títulos de anticorpos para E.canis, pela técnica de $\mathrm{IFI}$, em um cão experimentalmente infectado.

\section{Discussão}

No presente trabalho, a infecção experimental de um cão saudável, por via intravenosa, com 2,5 $\mathrm{ml}$ de sangue oriundo de um cão clinicamente doente, resultou em uma doença branda, de rápida evolução e que se resolveu naturalmente em poucos dias e cuja parasitemia sanguínea foi demonstrada por curto período de tempo, concordando com Almosny (1998) que, trabalhando com nove cães sem raça definida observou que a gravidade dos sintomas variou entre os animais estudados, embora a maioria deles tenha apresentado um quadro clínico discreto. Outros autores (Rikihisa et al., 1992; Waner et al., 1996; Harrus et al., 1998) observaram alterações clínicas e hematológicas mais consistentes; entretanto, infectaram animais das raças Beagle e Pastor Alemão com inóculos maiores. Para Harrus et al. (1997b), há suscetibilidade racial na ehrlichiose canina, sendo que animais sem raça definida são considerados mais resistentes à doença e segundo Gaunt et al. (1996), a via de administração e o tamanho do inóculo podem influenciar o curso das infecções experimentalmente induzidas. Para Waner e Harrus (2000), os sinais da fase aguda variam em severidade mas usualmente resolvem-se espontaneamente, embora muitos cães possam permanecer subclinicamente infectados e daí evoluírem para a fase crônica que, segundo lqbal et al. (1994), pode resultar tanto em alta mortalidade como em recuperação clínica dos cães, os quais se tornam portadores e podem servir como fonte de infecção.

Sendo assim, a ehrlichiose canina exige métodos de diagnóstico seguros e precoces. $O$ exame direto com identificação de mórulas de E.canis em esfregaços de sangue periférico não é confiável, visto que poucas células se apresentam infectadas e não são usualmente detectadas (Woody e Hoskins, 1991; Iqbal et al., 1994; Harrus et al., 1997a). O isolamento em cultivo celular, embora o mais fidedigno, é dificultado pelas condições e pelo tempo requeridos. O PCR, altamente específico e sensíve,I ainda não apresenta uso rotineiro. Em relação à sorologia, se dispõe de testes comerciais do tipo ELISA e IFI. Recentemente, Harrus et al. (2002) comparando, três testes sorológicos do tipo ELISA, detectaram uma baixa sensibilidade destes para títulos menores que 1:320. Para Waner e Harrus (2000), dentre as provas sorológicas, o teste de IFI é o mais largamente utilizado e considerado padrão para detecção e titulação de anticorpos para a $E$. canis. A presença de títulos em uma diluição maior que 1:40 é considerado evidência de exposição.

Neste experimento, a reação de IFI foi realizada utilizando-se como antígeno células DH82 com alto nível de infecção por $E$. canis, como preconizado por Rikihisa et al. (1992); lqbal e Rikihisa (1994 b); Waner et al. (1996); Keysary et al. (2001) e Harrus et al. (2002). Durante o curso da doença houve soro conversão do cão infectado e a evolução de anticorpos específicos para E.canis foi demonstrada, com títulos de 1:320 no 10 dia e 1:1280 no $40^{\circ}$ dia pós-infecção. Estes dados são concordantes com os trabalhos de Weisinger et al. (1975) que, estudando a cinética de produção de anticorpos na ehrlichiose canina pela técnica IFI, detectaram títulos máximos de 1:1280 enquanto Keysary et al. (1996) e Waner et al. (1996), em trabalhos semelhantes, encontraram títulos que variaram de 1:160 a 1:640 na fase aguda da doença. Nos experimentos realizados por Rikihisa et al. (1992), lqbal et al. (1994) e lqbal e Rikihisa (1994b) foram detectados títulos bem superiores e que alcançaram 1:40960. Entretanto, estes autores utilizaram na infecção experimental cães da raça Pastor Alemão, sabidamente bem mais sensíveis à ehrlichiose, assim como fizeram inoculações endovenosas de $10^{-7}$ células DH82 infectadas com E.canis. Para Gaunt et al. (1996), a soro-conversão é uma resposta dose dependente.

O desenvolvimento de testes sorológicos só se tornou viável a partir do crescimento e propagação da E.canis em células de linhagem contínua, especialmente a DH82, que se mostrou receptiva para tal finalidade (Harrus et al., 1997a). Neste experimento, o isolamento e a propagação da E.canis em culturas de células $\mathrm{DH} 82$ foi efetivamente realizada e a cultura mostrou-se positiva no 18 dia pós infecção. O tempo requerido para observação de positividade em cultivo celular pode ser variável. Dawson et al. (1991 a), em inocùlações sucessivas de cultivo primário de monócitos sangüíneos em células DH82, obtiveram positividade no 24으 dia pósinoculação Para Rikihisa et al. (1992), este tempo pode situar-se entre 20 a 50 dias, enquanto lqbal et al. (1994) o reportam na faixa de 14 a 34 dias. Iqbal e Rikihisa (1994b) isolaram $E$. canis do sangue de cães experimentalmente infectados 
e posteriormente tratados com doxiciclina, após 34 a 51 dias de cultivo. Keysary et al. (1996), ao caracterizarem a cepa Israeli, observaram $40 \%$ de células DH82 infectadas já no 10 dia pós inoculação. Alguns parâmetros podem ser levados em consideração como responsáveis pela variação no tempo de isolamento, como por exemplo, o tamanho e o nivel de infectividade do inóculo utilizado, o uso ou não de antibióticos nas culturas, a metodologia de observação, e a incubação das culturas em estufa comum ou de CO2. Para lqbal e Rikihisa (1994b), o tempo requerido para uma cultura tornar-se positiva é diretamente proporcional ao número de organismos de $E$. canis e/ ou ao número de monócitos infectados no sangue.

No presente trabalho, tanto a técnica histoquímica do PanoticoLB como a imunofluorencência direta permitiram evidenciar mórulas intracitoplasmáticas, assim como avaliar o nível de infecção, como postulado por Gaunt et al. (1996) e Dawson et al. (1991a).

À semelhança dos trabalhos de Dawson et al. (1991a), este isolamento alcançou $80 \%$ de infecção no $47^{\circ}$ dia e as culturas foram divididas a $1: 2$, retornando rapidamente a este patamar, quando então algumas amostras foram congeladas como preconizado por Doyle (1990). Estes resultados viabilizaram uma fonte constante e contínua de antígeno para a técnica de IFI.

O antígeno de E.canis obtido no presente estudo será utilizado como ferramenta diagnóstica assim como na determinação da soro-prevalência da ehrlichiose canina. A E.canis, isolada e propagada pela primeira vez no Brasil, poderá contribuir, ainda, para estudos da relação filogenética com as cepas até então padronizadas.

\section{Agradecimentos}

Ao Prof. Cláudio de Morais Andrade, do Laboratório de Viroses Veterinárias da UFRRJ, pela colaboração e assessoria no cultivo celular. À seção de Diagnóstico de Raiva do Instituto Municipal de Medicina Veterinária Jorge Vaitsman, pela elaboração do conjugado para a IFD. À FAPERJ, pelo apoio financeiro na aquisição das células DH82.

\section{Referências}

ALMOSNY, N.R.P. Ehrlichia canis (Donatien \& Lestoquard, 1935) : Avaliação parasitológica, hematológica e bioquimica sérica da fase aguda de cães e gatos experimentalmente infectados. $1998.141 \mathrm{f}$. Tese (Doutorado) - Instituto de Biologia - Universidade Federal Rural do Rio de Janeiro, 1998.

CARTER, G.B.; SEAMER, J.; SNAPE, T. Diagnosis of Tropical Canine Pancitopenia (Ehrlichia canis infection) by Immunofluorescence. Rev. Vet. Sci., v. 12, p. 318-322, 1971.

COSTA, J.O.; BATISTA, J.A.; SILVA, M.; GUIMARÃES, M.P. Ehrlichia canis infection in dogs in Belo horizonte-Brazil. Arq. Esc. Vet., n. 25, v. 2 , p. 199-200. 1973.

DAWSON, J.E.; ANDERSON, B.E.; FISHBEIN, D.B.; SANCHEZ, J.L.; GOLDSMITH, C.S.; WILSON, K.H.; DUNTLEY, C.W. Isolation and characterization of Ehrlichia sp. from a patient diagnosed with human ehrlichiosis. J. Clin. Microbiol., v. 29, n.12, p. 2741-2745, 1991 a.

DAWSON, J.E.; RIKIHISA, Y.; EWING, S.A., FISHBEIN, D.B. Serologic diagnosis of a human ehrlichiosis using two Ehrlichia canis isolate. J. Infect. Dis., v. 163, p. 564-567, 1991b.

DOYLE, A. Establisment of lymphoblastoid cell lines. In: POLLARD, J.; WALKER,J.M. (Ed.). Methods in Molecular Biology, v. 5. Animal Cell Culture. New Jersey: Humana Press, 1990. p. 33.

GAUNT, S.D.; CORSTVET, R.E.; BERRY, C.M.; BRENNAN, B. Isolation of Ehrlichia canis from dogs following subcutaneous inoculation. J. Clin. Microbiol., v. 34, n. 6, p. 1429-1432, 1996.

HARRUS, S.; BARK, H.; WANER, T. Canine Monocytic Ehrlichiosis: An update. Cont. Educ., v. 19, n. 4, p. 431-443, 1997a.

HARRUS,S.; KASS, P.H.; KLEMENT, E.; WANER, T. Canine Monocitic Ehrlichiosis: a retrospective study of 100 cases and an epidemiological investigation of prognostic indicators for the disease. Vet. Rec., v. 141, p. 360-363, 1997b.

HARRUS, S.; WANER, T.; AIZENBERG, I.; BARK, H. Terapeutic effect of doxycycline in experimental subclinical canine monocytic ehrlichiosis. Evaluation of a 6 week course. J. Clin. Microbiol., v. 36, p. 73-76, 1998.

HARRUS, S.; ALLEMAM, A R.; BARK, H.; MAHAN, S.M.; WANER, T. Comparison of three enzyme-linked immunosorbant assays with the indirect immunofluorescent antibody test for the diagnosis of canine infection with Ehrlichia canis. Vet. Microbiol. v. 86, p. 361-368, 2002 HEMELT, E.I.; LEWIS, G.E.; HUXOLL, D.L.; STEPHENSON, E.H. Serial progagation of Ehrlichia canis in primary canine peripheral blood monocyte cultures. Cornell Vet., n. 70, p. 37-42, 1980.

IQBAL, Z.; CHAICHANASIRIWITHAYA, W.; RIKIHISA, Y. Comparasion of PCR with other test for early diagnosis of canine ehrlichiosis. $J$. Clin. Microbiol., v. 32, n. 7, p. 1658-1658, 1994.

IQBAL, Z.; RIKIHISA ,Y. Aplication of the polymerase chain reaction for the detection of Ehrlichia canis in tissue dogs. Vet. Microbiol., v. 42, n. 4, p. 281-287, 1994 a.

IQBAL, Z.; RIKIHISA, Y. Reisolation of Ehrlichia canis from blood and tissues of dogs after doxycycline treatment. J. Clin. Microbiol., v. 32, n. 7, p. 1644-1649, 1994 b.

KEYSARY, A.; WANER, T.; ROSNER, M.; WARNER, C.K.; DAWSON, J.E.; ZASS, R.; BIGGIE, K.L.; HARRUS, S. The first isolation, in vitro propagation and genetic caracterization of Ehrlichia canis in Israel. Vet. Parasitol., v.2, p.331-340, 1996.

MASSARD, C. A. Ehrlichia bovis (Donatien \& Lestoquard, 1935). Diagnóstico, cultivoin vitro e aspectos epidemiológicos em bovinos no Brasil. 1984. $113 \mathrm{f}$. Tese (Doutorado). Instituto de Biologia- Universidade Federal Rural do Rio de Janeiro. 1984.

MUNHOZ, A.L. F.; BABO, V.J. Estudo retrospectivo das características da ehrlichiose canina. Hora Vet. Ano 18, n. 106, nov/dez. 1988, p. 39-43.

NYINDO, M.B.A.; RISTIC, M.; HUXOU, D.L; SMITH, A.R. Tropical Canine Pancytopenia: in vitro cultivation of the causative agent - Ehrlichia canis. Am. J. Vet. Res., v. 32, p. 1651-1658, 1971.

RIKIHISA, Y.; EWING, S.A.; FOX, J.C.; SIREGAR, A. G.; PASARIBU, F.H.; MALOLE, M.B. Analyses of Ehrlichia canis and Canine Granulocitic Ehrlichia infection. J. Clin. Microbiol., v. 30, p. 143-148, 1992.

RISTIC, M.; DAVID, L..; WISIGER, R.M.; PAUL, K.; NYINDO, M.B.A Serological diagnosis of tropical canine pancytopenia by indirect immunofluorescence. Infecf. Imm. v. 6, n. 3, p. 226-231, 1972.

RISTIC, M.; HOLLAND, C.J. Canine Ehrlichiosis. In: WOLDEHIWET, Z., RISTIC, M. (Ed.). Rickettsial and Chamydial Diseases of Domestic Animals. New York Pergamon Press, 1993. p. 169-186.

SEIBERT, M.; SILVA, N.R.S.; CHAPLIN, E.L.; ARAÚJO, F.A.P. Ocorrência de Ehrlichia (Rickettsiales: Rickettsiaceae) em cães conduzidos ao 
Hospital das Clínicas Veterinárias da Universidade Federal do Rio Grande do Sul-Brasil. Arq. Fac. Vet. UFRGS, Porto Alegre, v. 25, n. 2, p. 8494, 1997.

SIMPSON, C.F. Structure of Ehrlichia canis in blood monocytes of a dog. Am. J. Vet. Res., v. 33, n. 12, p. 2451-2454, 1972.

TROY, G.C.; FORRESTER, S.D. Canine ehrlichiosis In: GREENE,C.E. (Ed). Infectious Diseases of Dog and Cat. Philadelphia: WB Saunders Co, 1990. p. 404-414.

WANER, T.; ROSNER, M.; HARRUS, S.; NAVEH, A.;ZASS, R.; KEYSARY, A. Detection of ehrlichial antigen in plasma of beagle dogs with experimental acute Ehrlichia canis infection. Vet. Parasitol., n. 63, p. 331335, 1996.
WANER ,T.; HARRUS, S. Canine Monocytic Ehrlichiose (CME) in Recent Advances in Canine Infectious Disease. 2000. Disponivel na Internet www.ivis.org

WEISINGER, R.M.; RISTIC, M.; HUXSOLL, D.L. Kinetics of antibody response to Ehrlichia canis assayed by the indirect fluorescent antibody method. Am. J. Vet. Res., v. 36, n. 5, p. 689-694. 1975.

WELLMAN, M.L.; KRAKOWKA, S.; JACOBS, R.M.; KOCIBA, G.J. A macrophage-monocyte cell line from a dog with malignant histiocytosis. In Vitro Cell Dev. Biol., n. 24, p. 223-229, 1988.

WOODY, B.J.; HOSKINS, J.D. Ehrlichial diseases of dogs. Vet. Clin. North Am. Small Anim. Pract., v. 21, p. 75-98, 1991. 